\title{
Pangs of Proximity: Politico-Constitutional Crisis in Sri Lanka and its Implications on India-Sri Lanka Relations
}

\author{
Manoharan $\mathrm{N}^{*}$ and Riya Arundhati Pawar'
}

\begin{abstract}
The National Unity Government, formed by the traditional rivals UNP and SLFP, was a good example of 'cohabitation'. However, things started falling apart in due course due to new political realignments. It reached a stage where President Sirisena joined hands with the previous President Rajapaksa to oust Prime Minister Ranil Wickremasinghe resulting in about a two-monthlong politico-constitutional crisis. With judicial intervention, the crisis got over, but not permanently; the polity looks polarised. The crisis has wide-ranging implications, both at domestic and international levels, especially for India-Sri Lanka relations. Unprecedented political situation that has arisen in Sri Lanka has at least two broad implications on India-Sri Lanka relations: the state of Indian infrastructure projects in Sri Lanka and the ethnic issue in the island nation.
\end{abstract}

Keywords: Wickremasinghe, Sirisena, SLFP, UNP, SLPP, Rajapaksa

\section{Introduction}

In a surprising turn of events, on 26 October 2018 Sri Lankan President Maithripala Sirisena dismissed Prime Minister Ranil Wickremasinghe and appointed former President Mahinda

${ }^{*}$ CHRIST (Deemed to be University), Bengaluru, India;

manoharan.n@christuniversity.in

tCHRIST (Deemed to be University), Bengaluru, India;

riya.pawar@law.christuniversity.in 
Rajapaksa as the new Prime Minister. The deposed Prime Minister Wickremasinghe refused to step down claiming the move as unconstitutional. President Sirisena subsequently dissolved the Parliament and called for snap elections. Several petitions were filed in the Sri Lankan Supreme Court and the Court of Appeal challenging President's decisions. In its ruling, the Supreme Court ordered for reinstatement of Ranil Wickmasinghe and Parliament, ending a 51-day stand-off. In disposing a separate petition, the Court of Appeal revoked Mahinda Rajapaksa's prime ministership.

The article explores the factors that prompted the move by President Sirisena, who in fact teamed-up with Wickremasinghe to depose Rajapaksa in 2015. The article further analyses whether his action was right constitutionally and the short and long-term consequences to the country that has emerged out of a deadly ethnic conflict only a decade ago. In addition, the article studies the implications of this event on India-Sri Lanka relations?

\section{Politico-Constitutional Crisis}

To understand the politico-constitutional crisis, it is important to comprehend the background of events that began in late 2014. Current President Pallewatte Gamaralalage Maithripala Yapa Sirisena was the General Secretary of Sri Lanka Freedom Party (SLFP) and also Minister of Health in Rajapaksa government. He fell apart with President Rajapaksa and decided to contest presidential elections with the support of the United National Party (UNP) led by Ranil Wickremasinghe and some of his own party (SLFP) supporters (Independent, 2014).

In a surprising development, Mahinda Rajapaksa was voted out of power in the presidential elections by his one-time ally and cabinet colleague. Of the votes polled, Rajapaksa got 47.6 percent as against 51.3 percent by Sirisena. Undermining the strength of growing opposition, Rajapaksa called for elections two years ahead of the schedule assuming that he would win comfortably. At one point, he was equated by a significant chunk of majority Sinhalese to ancient king Dudugemunu for decimating the formidable LTTE militarily. However, as the majority Sinhala votes got split between the two leading candidates, minority votes - Tamils and Muslims - 
tilted in favour of Sirisena (Kelegama, 2015). But, votes for Sirisena and his new coalition, National Democratic Front, was more of anti-incumbency factor. People were concerned about the onset of authoritarianism in the governance process, human rights violations with impunity, apart from allegations of corruption and nepotism under Rajapaksa (Fox News, 2015).

Sirisena took over as the sixth executive president and gave leadership to broad coalition of government comprising of the United National Party (UNP) and SLFP, the two leading parties otherwise usually fought with each other in the political history of Sri Lanka. After a long gap, one of the Tamil leaders (Tamil National Alliance chief Sampanthan) became the leader of the opposition. Janatha Vimukthi Peramuna (JVP) known for its opposition to the UNP also extended support to the coalition government. The National Unity Government's main mantra was yaha palanaya ('good governance' in Sinhala) (Uyangoda, 2018). It meant ending of widespread corruption, nepotism, restoration of democracy, respect for human rights, and ethnic reconciliation. In the foreign policy arena, a "middle path" was pledged, as Rajapaksa leaned heavily towards China, alienating India and the West. Overall, it looked like a rare confluence of the President, Prime Minister and Leader of Opposition as one force.

Changes towards positive direction commenced under the new regime both within and outside the existing 1978 Sri Lankan Constitution. Constitutionally, 19th amendment to the Constitution, touching various aspects, was enacted in April 2015 (Amendment, 2015). A total of 56 changes were brought to the Constitution. With the amendment, the executive president was made relatively weaker and parliamentary system of government bit stronger. The 19th amendment also restored the two-term cap on the president that was removed by the $18^{\text {th }}$ amendment. The Amendment provided to establish a Constitutional Council consisting of 10 members (seven members of Parliament and three eminent persons) for the purpose of high profile public appointments. This provision was to check on nepotism, one of the major allegations against previous Rajapaksa regime.

Nine independent commissions were set up to make the process of governance more democratic and accountable.i The members of 
these commissions are appointed by President on the recommendation of the Constitutional Council. President's arbitrary power to appoint key positions like the Chief Justice, Judges of the Supreme Court and Court of Appeal, Attorney General, members of the Judicial Service Commission, Auditor General, Inspector General of Police and Secretary General of Parliament was also curtailed. Now, the President could make appointments only on the recommendation of the Constitutional Council. Through the amendment, the term of Parliament was reduced from six to five years. It was also provided that the President cannot dissolve the Parliament until the expiration of the four and half years of Parliament unless a resolution passed by Parliament with two-thirds majority.

Apart from amending the existing Constitution, Sirisena government presented a plan for a new constitution aimed at devolving power in January 2016. As per the plan, the government promised to strengthen democratic rights, promote national reconciliation, guarantee fundamental rights and freedoms that assure human dignity, promote responsible and accountable government, and respect the rule of law (Daily FT, 2016). The drafting of the new Constitution was underway. Six SubCommittees were appointed in May 2016 to assist the Steering Committee in its mandate of drafting a constitutional proposal. The six sub-committees were on Fundamental Rights, The Judiciary, Law and Order, Public Finance, Public Service and Centre Periphery Relations. The six sub-committees submitted their reports in the end of September 2017 to the Constitutional Assembly. But, local elections and no-confidence motion against Ranil Wickremasinghe slowed down the process (Salter, 2019). Moving further, the Right to Information Act was passed by Parliament in 2016 to give right for people to access the information of affairs of several organs and institutions of the government, but subject to certain restrictions. This move was in response to widespread demand and expectation on a transparent and accountable government, especially pertaining to public projects. ${ }^{\text {ii }}$

On the ethnic reconciliation, which was totally absent under Rajapaksa government, some of the initiatives taken by the National Unity Government included: 
- The establishment of 'The Conflict Resolution Commission' headed by former President Chandrika Bandaranaike Kumaratunga.

- National Centre for women-headed families in Killinochchi, a long felt need to help war widows.

- Decision to put in place a domestic mechanism with foreign technical expertise to probe into the allegations of war crimes.

- Commencement of process of drawing up a new constitution that aimed at eliminating causes that led to the ethnic issue.

- Relaxation of security restrictions all over the country, especially in the Tamil-dominated North and East and scaling down of lands occupied by military in the name of 'high security zones'.

- Commitment to a package of transitional justice measures.

- Setting up of the Office of Missing Persons and the Office of Reparations aimed at enhancing ethnic reconciliation.

The causes that prompted the politico-constitutional crisis requires analysis. Two broad reasons could be attributed: internal power struggles of the National Unity Government, especially between President Sirisena and Prime Minister Wickremasinghe and moves by Mahinda Rajapaksa to come back to power using the rifts in the coalition government.

Despite a promising start, fissures started emerging within a year of the coalition government in power. Personality clashes between Sirisena and Wickremasinghe came to affect policy decisions, especially in economic, foreign policy, domestic political structural changes and the ethnic issue (Perera, 2018). Ministers belonging to UNP and SLFP started criticising the other for the failures in open. It looked like each party wanted the other weakened in the eyes of the common man. Successes were owned and failures passed on.

On the economic front, there were differences on reforms in opening up services sector for FDI and on award of development projects. While Wickremasinghe preferred FDI flow in services 
sector, Sirisena was apprehensive of such a move. But, the most interesting difference was on the offer of development projects to foreign actors. In the initial period of assuming charge, the Unity Government reviewed and put on hold all those Chinese projects that were considered expensive. But, at a later date, President Sirisena's China tilt was evident when he started granting China infrastructure development projects in his hometown Polonnaruwa. This was a big U-turn on the part of Sirisena, who was critical of Rajapaksa on being "pro-China" in awarding multimillion projects during the latter's rule (Mushtaq, 2016). Wickremasinghe, on the other hand, wanted to give preference to India or Japan. During his India visit, just before his sacking in October 2018, Ranil Wickremasinghe was conveyed India's concerns on delays of its projects in Sri Lanka. Some of the pending projects include an LNG terminal with a floating re-gasification unit in Kerawalapitiya near Colombo, a $50 \mathrm{MW}$ solar power plant in Sampur, an oil tank facility in Trincomalee, housing project in the north for Tamils, and a container terminal in the Colombo port (Haidar, 2018). It is not a coincidence that Ranil Wickremasinghe was removed soon after his India trip.

On the ethnic question, both President Sirisena and Prime Minister Wickremasinghe by and large agreed on reversing excesses committed by the previous regime, international commitments on human rights, long-term political settlement and reconciliation. Yet, Sirisena could not ignore opposition arising from Sinhala hardliners and Buddhist Sangha. That's perhaps the reason why they have to reiterate giving foremost place to Buddhism in the new constitution as well. Ranil Wickremasinghe noted that "I informed the Mahanayaka Theras that I have already spoken to opposition political parties and have come to an agreement not to change the wordings of Article 9 of the Constitution which gives the foremost place to Buddhism" (Daily Mirror, 2018). Article 9 is the only article that figures under Chapter II titled 'Buddhism'. The article reads: "The Republic of Sri Lanka shall give to Buddhism the foremost place and accordingly it shall be the duty of the State to protect and foster the Buddha Sasana, while assuring to all religions the rights granted by Articles 10 and 14(1)(e)." Anyone with political ambitions at the national level cannot tinker with this provision. 
There were also clashes over the work culture. President Sirisena alleged that "Prime Minister Ranil Wickremesinghe arrogantly and stubbornly avoided collective decisions, and tended to take individual decisions. This behaviour led to many conflicts. Due to his lack of collective decision making through discussion, our country had to face harsh consequences when he used to take decisions with a group of his very close associates" (Daily News, 2018). He went on to add that "Wickremesinghe grossly violated the very principles of good governance we pledged to uphold" (Ibid.).

Mahinda Rajapaksa had been wanting to come back to power since he lost both presidential and parliamentary polls in January and August 2015 respectively. One of the reasons for the power bid is to gain immunity from prosecutions of omissions and commissions during his reign from 2005 to 2015. Major boost came in the form of landslide victory in local elections held in February 2018. His newly formed Sri Lanka Podujana Peramuna (SLPP) secured 231 local councils, with 3369 of its candidates elected as council members. Ranil's United National Party (UNP) won 34 councils and Sirisena's Sri Lanka Freedom Party (SLFP) and the United People's Freedom Alliance, secured only nine councils. Rajapaksa interpreted the results as a referendum against the incumbent Unity Government. He called for dissolution of Parliament and holding of snap elections. He positioned himself as a leader of the anti-government sentiments. But, election results would have been different had UNP and SLFP fought together instead of pitting against each other and in the process pulling the very unity of the government at Colombo of which they were part of. Post the local election results, some of the SLFP parliamentarians and supporters started gravitating towards Rajapaksa.

In April 2018, the former president Rajapaksa moved a no confidence motion in parliament against Ranil Wickremasinghe. The motion, however, was defeated, thanks to support by all minority parties. When he could not unseat the Unity Government in parliament, he took to streets. He organised a five-day public march from Kandy to Colombo (about 100 kilometres), and a rally in August 2018 with slogans like "Against the constitution to divide the country" and "Oppose punishing war heroes." He 
thundered: "I have a huge responsibility. Democracy is slowly fading away and dictatorship is rising as elections are being postponed. We are not able to speak up in Parliament. There is no one to do the work of the Opposition, so we have come to the

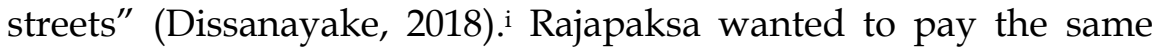
coin back to the forces which unseated him in 2015. Adding to these political protests, in July 2018, postal, health and teachers began their strike demanding increase in wages. Economic situation also deteriorated due to depreciation in rupee, balance of payment crisis, increase in foreign debt, fall in foreign exchange reserve, and inflation. Trade deficit in 2016 was USD 500 million; per capita GDP came down to USD 3835 from USD 3853 in 2014. In 2017, foreign exchange reserves were low at about USD 5 bn (Amarasuriya, 2017). But, these economic issues could not be attributed to the Unity government alone, but have been going on since Rajapaksa period.

All these anti-government commotions by the self-made "joint opposition" seemed to have rattled President Sirisena. The best way-out to Sirisena was to align with the opposition led by Rajapaksa. Being with Ranil would not make much sense to Sirisena, especially if he wanted to bid for second term as president. On the other hand, going along with Rajapaksa, whose popularity was on the upswing now, made a lot of sense. It was a mutually convenient alliance: a getaway for Sirisena; a window of opportunity for Rajapaksa. But, the alignment could not be done with Ranil Wickremasinghe in power. So, President Sirisena cited "political problems, economic troubles, and the strong plot to assassinate me" as the reasons to remove Wickremesinghe from the prime ministership (Daily News, 2018). He went ahead and appointed former president Mahinda Rajapaksa as the new Prime Minister knowing well lack of majority. Calling his removal as "unconstitutional", Ranil refused to step down and in fact asked for an emergency session of parliament to prove his majority. But, the President initially suspended the house and later dissolved it and called for fresh elections. For some weeks, there were two prime ministers in Sri Lanka. The political drama continued until the intervention of the Supreme Court. 
During the ruling, the Supreme Court on 13 December 2018 (Judgement, 2018) rejected "independent, overarching and unfettered power upon the President to dissolve Parliament at his sole discretion and without reference to Article 70..." It further observed: "...this court has time and time again stressed that our law does not permit vesting unfettered discretion upon any public authority whether it be the president or any officer of the state." Supreme Court's unanimous judgement stated, “...the principle enunciated by this Court is that all three organs of Government have an equal status and must be able to continue to be able to maintain effective checks and balance on each other" (Ibid.). Ranil Wickremasinghe also proved his majority in parliament that was convened at the behest of the apex court.

\section{Implications}

The crisis has wide-ranging implications, both at domestic and international levels, especially for India-Sri Lanka relations.

\subsection{Domestic Implications}

At the domestic level, there are two major challenges that have unfolded:

Firstly, the latest political crisis that came out in open is a clear indication of deeply fractured polity. The cohabitation between President Sirisena and Prime Minister Ranil Wickremasinghe is unlikely to work. Although the Prime Minister Wickremasinghe said that he has "no problem in working with Sirisena", the President has made it clear that he was "not ready to work with Ranil Wickremesinghe at any cost" (Daily Mirror, 2018). This means that there are several landmines in store in the functioning of the government. This got reflected in the very distribution of portfolios after the reinstatement of Wickremasinghe. President holds Defence Ministry along with control over law and order, in effect command over the entire defence and police forces. Hold over police indicates that the President could influence all investigations on corruption and other charges on Rajapaksa. He is also likely to order investigations on the alleged plot to assassinate him. Of late, President Sirisena and former President Rajapaksa are seen together is political and social events. On the other hand, 
Prime Minister Wickremesinghe is left with National Policies, Economic Affairs, Resettlement \& Rehabilitation, Northern Province Development, Vocational Training \& Skills Development \& Youth Affairs. One is not sure how long this government is going to last. But, whatever it may be, cooperation between Prime Minister and President in smooth functioning of the government is not likely.

The political instability has impacted the already shaky economy. Credit rating agencies Fitch and Standard \& Poor's have downgraded Sri Lanka, citing refinancing risks and an uncertain policy outlook (Aneez, 2018). Low business confidence in the country has resulted in capital outflow and dwindling foreign investments. Rupee has depreciated by more than 10 percent between October to December 2018 (Yusuf, 2018). The crisis has even resulted in delay in presentation of budget for 2019. Tourism that contributes five percent of Sri Lanka's GDP also received set back during the period fearing untoward incidents. Some of the donors have withheld funds, notable example being US Millennium Challenge Corporation that was to pay USD 450 million (Samarasinghe, 2018).

Secondly, the crisis has turned the clock back on reconciliation on the ethnic issue. There is a big question mark on the state of the new constitution that has been on the making. Former President Rajapaksa has already been campaigning that the proposed new constitution is "divisive" and he was categorical when he said: "We managed to rescue the country, when the LTTE was trying to divide it. It will be silly to think that we will allow the country to be divided through a Constitution" (The Daily Mirror, 2019). Writing on the wall is clear: the new constitution is a still-born baby. Replacement of a Tamil member of parliament (R. Sampanthan) with former president Rajapaksa as the leader of opposition has not gone well with the minority communities. Similar to two prime ministers for some time, there were two opposition leaders. At this juncture, it looks doubtful whether all measures taken on ethnic reconciliation and in bringing a long-term settlement to the ethnic issue would move forward. 


\subsection{Implications on India-Sri Lanka Relations}

India-Sri Lanka relations took an unpleasant turn following the constitutional crisis that unfolded in Colombo. Significantly, Prime Minister Ranil Wickremesinghe's was sacked within a week of his official visit to India. New Delhi reacted to the constitutional crisis with a hope "that democratic values and constitutional process will be respected" (The Economic Times, 2018). However, the unprecedented political situation that has arisen in Sri Lanka has at least two broad implications on India-Sri Lanka relations: the state of Indian infrastructure projects in Sri Lanka and the ethnic issue in the island nation.

India has initiated several infrastructure projects in Sri Lanka aimed at the socio-economic development of the island state. Some notable projects include upgrading the Colombo-Matara rail link, reconstruction of the historic Medawachchiya to Madhu, Madhu to Talaimannar and Omanthai to Pallai railway lines, 500 MW Trincomalee power plant, inter-connection of electricity grids between India and Sri Lanka, restoration of harbour at Kankesanthurai, airfield at Palaly that became dysfunctional due to the ethnic conflict, a LNG terminal near Colombo, 3400 toilets in Batticaloa, Gram Shakti housing project in Southern Province, 3000 rain water harvesting units in Jaffna, establishment of multi-ethnic linguistic school in Polonnaruwa, construction of Jaffna Cultural Centre, renovation of 27 schools in Northern Province (Ministry of External Affairs, 2017). All these projects, however, remain incomplete mainly due to delays by the host nation. The crisis or a change in regime is expected to further delay the projects or even their scrapping.

Though Sri Lanka tried to offer projects to both India and China, the latter is the preferred choice. China has a track record of timely completion of projects, but mainly due to Beijing's disregard for issues like ethnic reconciliation and long-term political settlement on the ethnic question. When he was President from 2005 to 2014, Rajapaksa was comfortable with China. During his short return to power as prime minister, Rajapaksa approved a multi-million dollar port deals with China (Aneez, 2018). Also, since China is far away, any extra-regional power's involvement in Sri Lanka is not an issue as long as it serves its strategic and economic interests. 
India is not anxious about China's involvement in Sri Lanka but looks at the long-term strategic implications. The possibility of military use of port and other infrastructure by Chinese in Sri Lanka against India assumes importance. But, India stands out because of significant benevolence in its economic involvement in the island state.

On the settlement of the ethnic issue, India has consistently maintained that it favoured "a politically negotiated settlement acceptable to all sections of Sri Lankan society within the framework of an undivided Sri Lanka and consistent with democracy, pluralism and respect for human rights." For India, the full implementation of the $13^{\text {th }}$ Amendment provisions as an interim arrangement and going beyond it towards permanent settlement matters most.

However, Colombo thought differently after the decimation of the LTTE. The then President Rajapaksa, initially promised to look "beyond 13 th Amendment" through All Party Representative Committee (APRC). But, in military triumphalism, he changed stance and started to denounce that "there is no ethnic issue, but only development issue." At a later date, he went on to constitute a Parliamentary Select Committee (PSC) to look into the existing 13th Amendment framework that devolved powers to provinces in the country.

Unfortunately, from the outset the $13^{\text {th }}$ Amendment proved a political challenge. Apart from non-participation of opposition parties in the PSC, Sinhala hardline parties like Janata Vimukthi Peramuna (JVP), National Freedom Front (NFF) and Jathika Hela Urumaya (JHU) wanted to delete the existing $13^{\text {th }}$ Amendment. Ironically, a dominant section of the then Rajapaksa government supported this stance of the hardline parties, through the "13th Amendment Minus" arrangement. India was disappointed with this development.

However, with the regime change in 2015 the political situation looked positive. The new President Sirisena proposed a new constitution in January 2016 and subsequently a Constituent Assembly was established in March 2016 to draft a new document. Prime Minister Ranil Wickremasinghe who headed the Steering 144 
Committee of the Constituent Assembly submitted an interim report in November 2017. The report highlighted issues like principles of devolution, state land, provincial subjects, second chamber, electoral system, and public security. Although the interim report talks of "aekiya raajyaya" and "orumiththa nadu" (respectively Sinhala and Tamil terms for undivided and indivisible country), opposition to the draft has already emerged from the Buddhist clergy and Sinhala hardliners. Rajapaksa has been vociferous in his opposition to the new constitution (Hindustan Times, 2017).

India has also pushed for ethnic reconciliation in post-conflict Sri Lanka both at bilateral and multilateral levels. New Delhi firmly believes that without ethnic reconciliation, it is difficult to find a lasting political solution. India's stand at the UN Human Rights Council was progressive and positive: to push the reconciliation process seriously so that war-torn Sri Lankan society could rebuild itself in a sustainable manner. But with the return of Rajapaksa as Prime Minister, the situation seems like it would regress rather than progress.

Lately, some of India's South Asian neighbours have found it a challenge to uphold democratic values in their countries. Sudden developments in Sri Lanka have come as a challenge for New Delhi's neighbourhood policy. India has always supported Sri Lanka during crises and safeguarded the island nation's unity, territorial integrity and sovereignty. The trajectory of India-Sri Lanka relations since independence have evolved and, in the present context, serve as a model of good neighbourly relations. No wonder Mahatma Gandhi once rightly referred to Sri Lanka as India's "daughter state". This maxim should be borne in mind to ensure that India-Sri Lanka relations do not deteriorate further.

\section{Conclusion}

The National Unity Government formed by confluence of traditionally rival political parties - UNP and SLFP - gave immense hope to the people of Sri Lanka in terms of good governance and cordial foreign relations with all countries. But, things started 
falling apart within a year due to sheer political interests of the leaders at the helm. It reached a stage where the current President joined hands with the previous President to oust the Prime Minister resulting in about a two-month-long politicoconstitutional crisis. With judicial intervention, the crisis got over, but not permanently. Given the differing interests, it is likely to recur, leading to policy paralysis. As a result, the country got downgraded on its economic performance; Sri Lanka's image in the international arena went down; protests increased; and people's confidence dwindled. This is not good for a small island country that has emerged from a long ethnic war just a decade ago.

Currently, the polity looks polarised. The fruits of development will be lost if the two main parties - UNP and SLFP - continue to play 'plebiscitary politics'. It is important that the Sri Lankan government counts-in the Opposition's contribution in the nationbuilding. At this juncture, without bi-partisan consensus, socioeconomic development or any political settlement to the ethnic question would be unsustainable. Political history of Sri Lanka since independence is a witness to this.

Most crucially, the impact of the crisis on India-Sri Lanka bilateral relations cannot be ignored. India's infrastructure projects and ethnic reconciliation has taken a jolt due to the crisis. Former President Mahinda Rajapaksa is known for his pro-China leanings and anti-reconciliation stance. At this juncture, India has to patiently work for broad consensus both at societal and political levels on the ethnic issue. Without a island-wide consensus any settlement of the ethnic issue is doomed to be a failure. On the infrastructure projects, New Delhi need not to worry too much about China's presence. India has been doing its best in helping out Sri Lanka's socio-economic development for several years. There is neither profit motive nor strategic angle to India's assistance to its neighbours.

\section{References}

Amarasuriya, M. (2017, October 25). Whither Sri Lanka's Economy. Daily Mirror. Retrieved from http://www.dailymirror.lk/article/WhitherSri-Lanka-s-economy-139148.html 
Amendment. (2019). Retrieved from https:// www.parliament.lk/ files/ pdf/constitution/19th-amendment-bill-gazette.pdf on 20 February 2019.

Aneez, S. (2018, December 4). Rating agencies downgrade Sri Lanka amid political crisis. Reuters. Retrieved from https://in.reuters.com/ article/us-sri-lanka-ratings-s-p/rating-agencies-downgrade-sri-lankaamid-political-crisis-idINKBN1O30YU

Aneez, S. (2018, November 29). Sri Lanka signs port deals with China amid political upheaval. Reuters. Retrieved from https:// www.reuters.com/article/us-sri-lanka-china/sri-lanka-signs-portdeals-with-china-amid-political-upheaval-idUSKCN1NY19S

Daily FT. (2016). Govt. outlines plans for new Constitution to devolve power. Retrieved from http://www.ft.lk/article/518517/Govt-outlines-plans-for-new-Constitution-to-devolve-power

Daily Mirror. (2018, December 13). Not ready to work with Ranil at any cost: Prez. Daily Mirror. Retrieved from http:// www.dailymirror.lk/article/Not-ready-to-work-with-Ranil-at-anycost-Prez-159752.html

Daily Mirror. (2018, December 28). PM assures foremost place to Buddhism. Retrieved from http://www.dailymirror.lk/ breaking news/PM-assures-foremost-place-to-Buddhism/108-160404

Daily News. (2018, October 29). President reveals of Ministerial hand to assassinate him. Retrieved from http:// www.dailynews.lk/ 2018/10/29/local/166851/president-reveals-ministerial-handassassinate-him

Dissanayake, C. (2018, September 6). MR pledges comeback. Daily FT. Retrieved from http://www.ft.lk/top-story/MR-pledges-comeback/ 26-662330

Fox News. (2015, January 3). Associated Press- Internal revolt, charges of corruption, nepotism threaten Rajapaksa's kingly hold on Sri Lanka.

Haider, S. (2018, October 20). Sri Lankan projects delayed, PM Modi tells Ranil Wickremesinghe. The Hindu. Retrieved from https:// www.thehindu.com/news/national/meeting-between-primeminister-narendra-modi-and-sri-lankan-prime-minister-ranilwickremesinghe/article25271952.ece

Hindustan Times. (28 January 2017). Will oppose Sri Lanka's new Constitution, says ex-president Mahinda Rajapaksa. Hindustan Times. Retrieved from https://www.hindustantimes.com/world-news/willoppose-sri-lanka-s-new-constitution-says-ex-president-mahindarajapaksa/story-Sino8lMHhXUQ5vvX1Rr2MJ.html

Judgement. (2018). Retrieved from http://supremecourt.lk/ images/ documents/sc_fr_351_2018.pdf on 1 March 2018. 
Kelegama, S. (2015, January 15). Sri Lankan presidential election at a glance - analysis. Institute of South Asian Studies. Retrieved from http://www.ips.lk/wp-content/uploads/2016/12/15Jan2015_ER.pdf on 15 January 2019

Mallawarachi, M. (2014, November 20). Sri Lankan President Mahinda Rajapaksa calls snap election amid row over his wide-ranging powers. Independent. Retrieved from https:// www.independent.co.uk/ news/world/asia/sri-lankan-president-mahinda-rajapaksa-callssnap-election-amid-row-over-his-wide-ranging-powers-9874094.html

Ministry of External Affairs. (2017). India-Sri Lanka Relations. Retrieved from https://mea.gov.in/ Portal/ ForeignRelation/ Sri_ Lanka_November_2017_NEW.pdf on 04 March 2019. The latest information of ongoing Indian projects in Sri Lanka is available at https:/ / hcicolombo.gov.in / ongoing_projects

Mushtaq, M. (2016, June 22). President Sirisena's second visit to Beijing to boost China-Sri Lanka ties. Asia Times. Retrieved from https:/ / cms.ati.ms/2016/06/president-sirisenas-second-visit-tobeijing-will-boost-china-sri-lanka-ties/

Perera, J. (2018, June 18). National Unity Government Needs to Govern with more Consensus. Colombo Telegraph. Retrieved from https:// www.colombotelegraph.com/index.php/national-unity-governmentneeds-to-govern-with-more-consensus/

Salter, M. (2019, February 23). Sri Lanka: In Search of Truth and Reconciliation. Colombo Telegraph. Retrieved from https:// www.colombotelegraph.com/index.php/sri-lanka-in-search-of-truthreconciliation/

Samarasinghe, S. (2018, December 2). The crisis in governance: likely economic consequences and the end game. The Island. Retrieved from http:/ / www.island.lk/index.php?page_cat=articledetails\&page $=$ article-details\&code_title $=195426$

The Daily Mirror. (2019, January 6). Won't allow the country to be divided through Constitution: MR. The Daily Mirror. Retrieved from http:// www.dailymirror.lk/breaking_news/Won-t-allow-the-country-to-bedivided-through-Constitution-MR/108-160733

The Economic Times. (2018, October 28). Hope democratic values would be respected: India on political turmoil in Sri Lanka. The Economic Times. Retrieved from https://economictimes.indiatimes.com/ news/politics-and-nation/hope-democratic-values-would-berespected-india-on-political-turmoil-in-sri-lanka/ articleshow / 66399955. cms

Uyangoda, J. (2018). Political crisis in Sri Lanka. Economic and Political Weekly, 53(49). 
Yusuf, M. (2018).Sri Lanka's constitutional crisis: Risks to the economy and growth. Daily FT. Retrieved from http://www.ft.lk/opinion/SriLanka-s-constitutional-crisis--Risks-to-the-economy-and-growth/14667766

\section{Endnotes}

${ }^{i}$ The nine independent commissions were the Election Commission, the Public Service Commission, the National Police Commission, the Human Rights Commission of Sri Lanka, the Commission to Investigate Allegations of Bribery and Corruption, the Finance Commission, the Delimitation Commission, the National Procurement Commission, and the Audit Service Commission

ii Article 14A was inserted in the Constitution under the title 'Right of access to information'. But information could be withheld "in the interests of national security, territorial integrity or public safety, for the prevention of disorder or crime, for the protection of health or morals and of the reputation or the rights of others, privacy, prevention of contempt of court, protection of parliamentary privilege, for preventing the disclosure of information communicated in confidence, or for maintaining the authority and impartiality of the judiciary." 